\title{
HUBUNGAN LAMA MEROKOK, LAMA BERTUGAS DAN \\ ARUS LALU LINTAS KENDARAAN DENGAN KADAR TIMBAL (Pb) \\ DALAM RAMBUT POLISI LALU LINTAS DI KABUPATEN MAGELANG TAHUN 2016
}

\author{
Dyah Wulandari 1), Sugeng Abdullah ${ }^{2)}$, Yulianto ${ }^{3)}$ \\ Jurusan Kesehatan Lingkungan, Politeknik Kesehatan Kemenkes Semarang, \\ Jl.Raya Baturraden KM 12 Purwokerto, Indonesia
}

\begin{abstract}
Latar belakang cemaran timbal $(\mathrm{Pb})$ di lingkungan merupakan hasil pembakaran $\mathrm{Pb}$-alkali pada bahan bakar kendaraan bermotor yang dapat terhirup oleh manusia. Kebiasaan merokok juga diketahui meningkatkan kadar timbal $(\mathrm{Pb})$ dalam tubuh. Polisi lalu lintas yang bertugas di jalan raya akan selalu terpapar oleh timbal $(\mathrm{Pb})$ yang berasal dari emisi kendaraan bermotor. Tujuan penelitian ini untuk mengetahui hubungan lama merokok, lama bertugas dan arus lalu lintas kendaraan dengan kadar timbal $(\mathrm{Pb})$ dalam rambut polisi lalu lintas. Metode penelitian menggunakan observasional analitik dengan pendekatan Cross Sectional. Penelitian ini dilakukan di 5 pos jaga lantas di Kabupaten Magelang. Sampel rambut polisi diperiksa di laboratorium. Hasil penelitian menunjukkan rerata kadar timbal $(\mathrm{Pb})$ dalam rambut 6,02 ppm. Hasil analisis uji korelasi Simple Regression menunjukkan variabel yang berhubungan adalah lama merokok (R 0,504;p 0,047) dan arus lalu lintas kendaraan ( $\mathrm{R}$ 0,661;p 0,019) sedangkan lama bertugas tidak berhubungan dengan kadar timbal $(\mathrm{Pb})$ dalam rambut. Analisis Uji Regressi Linier Ganda menunjukkan tidak terdapat hubungan antara ketiga variabel independen dengan kadar timbal $(\mathrm{Pb})$. Simpulan, tidak ada hubungan antara lama merokok, lama bertugas dan arus lalu lintas dengan kadar timbal $(\mathrm{Pb})$ dalam rambut Polisi Lalu Lintas.
\end{abstract}

Kata Kunci: Kadar Timbal (Pb), Rambut Polisi Lalu Lintas, Kesehatan Linkungan

\begin{abstract}
[The Correlation Of Smoking Duration, Job Duration, And Vehicle Traffic With Lead (Pb) Level In Traffic Police's Hair In Magelang Regency Year 2016] Background contamination of lead $(\mathrm{Pb})$ in the environment is the result of $\mathrm{Pb}$-alkali burning motor vehicle fuel that can be inhaled by humans. Smoking habits are also known to increase levels of lead $(\mathrm{Pb})$ in the body. The traffic police have a function on the highway would always be exposed to lead $(\mathrm{Pb})$, which comes from vehicle emissions. The purpose of this study to determine the relationship of smoking duration, job duration and vehicle traffic with high levels of lead $(\mathrm{Pb})$ in traffic police's hair. The research method uses analytic observational with cross sectional approach. This research was conducted for one day at 5 guardhouse and then in Magelang Regency. The sampel was examined in agriculture laboratory Unsoed. The result of the research shows that the average level of lead $(\mathrm{Pb})$ in hair $6.02075 \mathrm{ppm}$. Simple correlation analysis results showed the variables related Regression is old smoke ( $\mathrm{R} 0.504 ; \mathrm{p} 0.047)$ and of vehicle traffic ( $R$ 0.661; p 0.019), while long-time employee is not related to levels of lead ( $\mathrm{Pb})$ in hair. The result of Multiple Linear Regression Test shows that there was no correlation between the three independent variables with lead $(\mathrm{Pb})$ level. The conclusion of the research is there is no correlation of smoking duration, job duration, and vehicle traffic with lead $(\mathrm{Pb})$ level in traffic police's hair.
\end{abstract}

Key words: Lead $(\mathrm{Pb})$ Level, Traffic Police's Hair, and Environmental Health

\section{PENDAHULUAN}

Kesehatan merupakan hak asasi manusia dan salah satu unsur kesejahteraan yang harus diwujudkan sesuai dengan cita-cita bangsa Indonesia, sebagai mana dimaksud dalam pancasila

1) dyah.wulandari60@yahoo.com

2) sugengzend@gmail.com

3)yulianto_61@yahoo.com dan undang-undang Dasar Negara Republik Indonessia Tahun 1945, setiap kegiatan dalam upaya untuk memelihara dan meningkatkan derajat kesehatan masyarakat yang setinggi-tingginya dilaksanakan berdasarkan prinsip nondiskriminatif, partisipatif dan berkelanjutan dalam rangka pembentukan sumber daya manusia Indonesia, serta meningkatkan ketahanan dan daya saing bangsa bagi 
pembangunan nasional (Undang-undang Nomor 36 Tahun 2009).

Data Kementerian Lingkungan Hidup Indonesia menunjukkan pemanfaatan timbal $(\mathrm{Pb})$ pada bahan bakar kendaraan bermotor merupakan penyebab utama terjadinya pencemaran timbal pada lingkungan dibeberapa kota besar di Indonesia.

Pertumbuhan ekonomi dan perkembangan sektor pariwisata yang meningkat pesat di Kabupaten Magelang, telah memberikan pengaruh yang sangat besar terhadap perkembangan sektor transportasi, terutama pada prasarana lalu lintas dan angkutan jalan. Semakin banyak orang melakukan perjalanan, berakibat langsung pada peningkatan mobilitas kendaraan di jalan raya. Menurut data Dinas Perhubungan (Dinhub) Kabupaten Magelang tahun 2014 jumlah kendaraan wajib uji mengalami peningkatan 2,6\% dari tahun 2013 dengan jumlah total 9331 untuk tahun 2013 dan 9555 untuk tahun 2014. Selain itu Menurut data Unit Pelayanan Pendapatan dan Pemberdayaan Aset Daerah (UP3AD) dan Samsat Kabupaten Magelang Jumlah objek kendaraan pada tahun 2014 adalah 244.215 dan tahun 2015 247.943, sehingga berdasarkan data tersebut di pastikan Jumlah kendaraan di Kabupaten Magelang mengalami peningkatan setiap tahunnya, dengan adanya jumlah kendaraan yang cukup tinggi, maka akan berdampak pada banyaknya kebutuhan bahan bakar.

Proses pembakaran bahan bakar tersebut akan menghasilkan banyak emisi yang berbahaya bagi kesehatan manusia, salah satunya timbal $(\mathrm{Pb})$. Cemaran timbal $(\mathrm{Pb})$ di lingkungan merupakan hasil pembakaran $\mathrm{Pb}$-alkali sebagai zat adiktif pada bahan bakar kendaraan bermotor. Saat proses pembakarannya, timbal $(\mathrm{Pb})$ dilepas ke lingkungan dalam bentuk debu atau partikulat yang dapat terhirup oleh manusia. Sehingga banyak kelompok masyarakat yang terpapar karena bahan pencemar timbal $(\mathrm{Pb})$, salah satunya adalah Polisi Lalu Lintas. Polisi lalu lintas memiliki fungsi di jalan raya akan selalu terpapar oleh timbal $(\mathrm{Pb})$ yang berasal dari emisi kendaraan bermotor. Potensi akumulasi timbal $(\mathrm{Pb})$ pada polisi lalu lintas menjadi lebih tinggi seiring lama paparan. Paparan tersebut bisa melalui jalur inhalasi. Selain bersumber dari emisi kendaraan bermotor, kadar timbal $(\mathrm{Pb})$ dalam rambut juga bisa berasal dari aktivitas merokok.

Timbal $(\mathrm{Pb})$ yang terhirup $10-30 \%$ diabsorpsi oleh paru-paru dan sekitar 5-10\% dari yang tertelan diabsorpsi melalui saluran cerna, sedangkan $30-40 \%$ timbal $(\mathrm{Pb})$ yang di absorpsi melalui saluran pernafasan akan masuk ke aliran darah. Pertama didistribusikan ke dalam jaringan lunak seperti tubulus ginjal dan sel hati, tetapi berinkorporasi dalam tulang, rambut, dan gigi untuk dideposit (Darmono, 1995, h. 97).

Paparan timbal $(\mathrm{Pb})$ dengan dosis rendah secara terus menerus yang berlangsung lama memiliki risiko terhadap kesehatan (Darmono,
1994, h. 97). Analisis logam berat dalam rambut adalah salah satu cara yang baik untuk memperkirakan kandungan unsur logam berat di dalam tubuh (Ferdiaz, 2011). Peneliti tertarik untuk melakukan penelitian dengan judul " Hubungan Lama Merokok, Lama Bertugas dan Arus Lalu Lintas Kendaraan dengan Kadar timbal $(\mathrm{Pb})$ dalam Rambut Polisi Lalu Lintas Di Kabupaten Magelang Tahun 2016".

Tujuan dalam penelitian ini yaitu untuk mengetahui hubungan lama merokok, lama bertugas dan arus lalu lintas kendaraan dengan kadar timbal $(\mathrm{Pb})$ dalam rambut polisi lalu lintas di Kabupaten Magelang.

\section{BAHAN DAN METODE}

Variabel independen dalam penelitian ini yaitu lama merokok, lama bertugas, dan arus lalu lintas kendaraan dan variabel dependen yaitu kadar timbal $(\mathrm{Pb})$ dalam rambut. Jenis penelitian adalah observasional analitik dengan pendekatan Cross Sectional atau penelitian yang mempelajari dinamika korelasi antara faktor resiko dengan efek, dengan pendekatan observasi atau pengumpulan data dalam satu waktu (point time approach). Artinya tiap subyek penelitian hanya diobservasi sekali saja dan pengukuran dilakukan terhadap status karakter atau variabel pada saat pemeriksaan.

Populasi dalam penelitian ini adalah Polisi Lalu Lintas yang bertugas di wilayah Kabupaten Magelang, yaitu Pos Armada, Pos Blondo, Pos Muntilan, Pos Salam, dan Sawitan yang memiliki masa kerja >3 tahun. Menurut Anies (Hadi Winarso, 2010) paparan timbal $(\mathrm{Pb})$ terhadap tenaga kerja akibat aktivitas di tempat kerja ditentukan secara nyata apabila mereka telah bekerja $>3$ tahun, tenaga kerja yang bekerja $<3$ tahun mungkin memiliki kadar $\mathrm{Pb}$ dalam darah dengan konsentrasi tertentu. Sampel dalam penelitian ini didapat dari populasi yang memenuhi kriteria inklusi, kriteria tersebut meliputi yaitu polisi lalu lintas yang bekerja di Pos Armada, Pos Blondo, Pos Muntilan, Pos Salam, dan Sawitan, telah bekerja >3 tahun, bersedia mengisi informed consent dan bersedia diambil rambutnya untuk diukur kadar timbal $(\mathrm{Pb})$ yang berjumlah 12 responden. Data diperoleh dengan cara observasi, wawancara, pengambilan sampel rambut dan dokumentasi. Instrumen yang digunakan berupa kuesioner, AAS (Atomic Absorption Spectrophotometer), tallicounter, dan stopwach/jam. Analisis data yang digunakan yaitu analisis bivariat menggunakan uji korelasi Simple Regression dan analisis multivariat menggunakan uji Regresi Linier Ganda.

\section{III.HASIL DAN PEMBAHASAN}

\section{Responden dan Pos Penjagaan}

Lokasi Pos yang dijadikan sebagai objek penelitian adalah pos jaga yang berada di Kabupaten Magelang sejumlah 5 pos yaitu Pos 
Armada, Pos Blondo, Pos Muntilan, Pos Salam, dan Sawitan. Pos-pos yang telah ditetapkan tersebut dipilih karena pada lokasi-lokasi tersebut merupakan pertigaan ataupun perempatan sehingga memunculkan kerawanan lalu lintas. Pos Armada terletak di depan simpangan jalan arah ke Yogyakarta, Semarang, Purworejo, dan arah ke Kota Magelang, Pos Blondo terletak di depan simpangan antara arah menuju Kota Yogyakarta dan arah ke Wisata Candi Borobudur maupun ke Ibu Kota Kabupaten Magelang, Pos muntilan terletak di dekat Pasar Muntilan, Pos Salam terletak di jalan arah Magelang-Jogja, dan Sawitan terletak di pertigaan sebelum Polres Magelang.

Jumlah polisi lalu lintas yang dijadikan sampel responden penelitian sebanyak 12 personil yang terdiri dari 3 personil Pos Armada, 6 personil Pos Sawitan, sedangkan untuk Pos Blondo, Pos Muntilan, dan Pos Salam masingmasing 1 personil. Setiap polisi memberikan rambutnya dalam jumlah yang bervariasi mulai dari 2 - 5 gram, hal ini dikarenakan panjang rambut antara satu polisi dengan polisi yang lainnya berbeda-beda. Pengambilan sampel rambut dilakukan pagi hari pukul 05.45 - 06.50 WIB di Aula Polres Magelang.

Rambut yang dijadikan sampel tidak memiliki persyaratan khusus pada saat pengambilannya, karena sampel rambut akan dicuci terlebih dahulu pada saat pemeriksaan di laboratorium.

\section{Lama Merokok}

Hasil penelitian menunjukkan rata-rata lama merokok responden adalah 2,9167 tahun, dari 12 responden diketahui hanya 4 responden yang memiliki kebiasaan merokok sedangkan sisanya tidak merokok. Lama merokok masingmasing responden bervariasi antara 0 tahun sampai 10 tahun. Lama merokok yang dihitung yaitu sudah berapa lama (tahun) responden memiliki kebiasaan merokok.

Menurut H.J. Mukono (2010) subyek beresiko tinggi terhadap paparan bahan pencemar udara adalah :

a. Individu yang berusia sangat muda dan sangat tua

b. Penderita asma

c. Penderita penyakit saluran pernafasan

d. Perokok.

Merokok diketahui mengganggu efektifitas sebagian mekanisme pertahanan respirasi. Produk asap rokok dapat merangsang produksi mukus dan menurunkan pergerakan silia. Penurunan pergerakan silia dapat merangsang terjadinya akumulasi mukus yang kental dan terperangkapnya partikel. Partikel yang dapat terperangkap dimukus salah satunya adalah timbal (Pb) (H.J. Mukono, 2010).
Rokok juga mengandung lebih dari 2000 substansi berbahaya termasuk timbal $(\mathrm{Pb})$. Timbal $(\mathrm{Pb})$ yang terdapat didalam rokok berasal dari daun tembakau selama proses penanaman (Hasan, 2013). Noor (Betti Ronayan A, 2015) juga menyebutkan secara alami kandungan timbal berasal dari tanah dan udara yang memang menyimpan timbal, selain itu pupuk NPK selama proses penanaman tembakau juga mempengaruhi kandungan timbal dalam tembakau.

Orang yang mempunyai kebiasaan merokok memiliki potensi terpapar timbal $(\mathrm{Pb})$ lebih besar dibandingkan orang yang tidak merokok baik paparan dari timbal $(\mathrm{Pb})$ dalam rokok itu sendiri maupun paparan dari udara yang tercemar timbal $(\mathrm{Pb})$. Kondisi tersebut juga didukung oleh penelitian Yustin MM dan MG Catur Y (2009) yaitu kebiasaan merokok dapat mempercepat penurunan fungsi organ salah satunya paru sehingga dapat mempertinggi toksikologi zat pencemar seperti timbal $(\mathrm{Pb})$. Sehingga ada baiknya seseorang mengurangi atau berhenti merokok sebagai upaya untuk meminimalisir terjadinya gangguan akibat zatzat kimia berbahaya yang berasal dari aktivitas merokok salah satunya timbal $(\mathrm{Pb})$.

\section{Lama Bertugas}

Menurut Anies (Hadi Winarso, 2010) paparan timbal $(\mathrm{Pb})$ terhadap tenaga kerja akibat aktivitas di tempat kerja ditentukan secara nyata apabila mereka telah bekerja $>3$ tahun. Rata-rata lama bertugas polisi lalu lintas di Kabupaten Magelang 7,33 tahun, dengan masa kerja paling lama 15 tahun. Jam kerja masing-masing responden setiap harinya bervariasi antara 4 jam sampai 12 jam perharinya.

Lama bertugas dapat mempengaruhi kadar timbal $(\mathrm{Pb})$ dalam rambut polisi lalu lintas karena semakin lama masa bertugas maka semakin lama pula paparannya, semakin lama paparan maka timbunan timbal dalam tubuh juga akan semakin banyak (Cecilia Oktaria, 2009). Kondisi demikian sangat merugikan orang-orang yang bertugas/kontak dengan polusi di jalan raya salah satunya adalah polisi lalu lintas. Polisi lalu lintas yang bertugas dijalan raya memiliki kontak emisi kendaraan yang mengandung timbal $(\mathrm{Pb})$.

Semakin lama masa kerjanya tidak secara absolut akan semakin tinggi pula kadar timbal $(\mathrm{Pb})$ dalam rambut. Hal ini bisa dipengaruhi oleh faktor lain seperti lama paparan timbal $(\mathrm{Pb})$ per harinya, kebiasaan merokok, maupun kedisiplinan menggunakan APD (masker).

Sebaiknya perlu dilakukan upaya untuk meminimalisir paparan timbal $(\mathrm{Pb})$ diantaranya dengan dilakukannya rotasi kerja atau bertugas, 
mengurangi kebiasaan merokok, serta penggunaan masker.

\section{Arus Lalu Lintas Kendaraan}

Tingkat emisi timbal $(\mathrm{Pb})$ salah satunya dipengaruhi oleh banyaknya kendaraan bermotor. Hasil pengukuran arus lalu lintas kendaraan dibeberapa wilayah pos jaga Satlantas Polres Magelang diperoleh rata-rata sebesar 4.620,33 kend/jam, dengan arus lalu lintas paling tinggi $8.944 \mathrm{kend} / \mathrm{jam}$ yaitu di Pos Armada, sedangkan arus lalu lintas paling rendah terjadi di daerah Sawitan dengan angka 2.268,33 kend/jam.

Pengukuran arus lalu lintas kendaraan dilakukan dengan menghitung kendaraan yang melewati masing-masing pos jaga dan sekitar Pos Jaga selama 1 jam pada jam-jam sibuk yaitu pagi (pukul 06.00-07.00 WIB), siang (pukul 13.00-14.00 WIB), dan sore (pukul 15.30-16.30 WIB). Penghitungan kendaraan dilakukan menggunakan tally counter dengan mengelompokkan jenis kendaraan menjadi 4 jenis yaitu sepeda motor, mobil, bus dan truk, serta Becak dan sejenisnya.

Hasil pengukuran arus lalu lintas kendaraan menurut jenis kendaraan diperoleh hasil sepeda motor dan mobil merupakan kendaraan yang mendominasi disetiap pos dengan jumlah rata-rata keseluruhan 16.648,98 kend/jam untuk sepeda motor dan 8.120,64 kend/jam untuk mobil, sedangkan yang paling sedikit melintas adalah becak dan sejenisnya. Sehingga dapat diketahui bahwa kendaraan bermotor dengan bahan bakar premium mempunyai jumlah yang lebih banyak dibandingkan kendaraan berbahan bakar solar maupun yang tidak berbahan bakar.

Bahan bakar bensin atau premium merupakan bahan bakar di Indonesia yang memiliki nilai oktan rendah yaitu 88 , sehingga untuk menaikkan nilai oktannya ditambahkan dengan timbal $(\mathrm{Pb})$. Setiap satu liter bensin yang dibakar jika dikonversi akan mengemisikan 0,56 g Pb yang dibuang ke udara (Librawati, 2005).

Semakin tinggi arus lalu lintasnya maka konsentrasi timbal $(\mathrm{Pb})$ di udara juga akan semakin tinggi, seperti yang disebutkan De Roes FJ (Wahyu Kurniawan, 2008) Kandungan timbal $(\mathrm{Pb})$ di udara sangat berhubungan dengan padat tidaknya arus lalu lintas kendaraan bermotor. Upaya yang dapat dilakukan untuk mengurangi kadar timbal $(\mathrm{Pb})$ di udara sebaiknya bisa dilakukan dengan cara pembuatan jalur hijau atau penanaman pohon dan pengurangan produksi bahan bakar yang mengandung timbal $(\mathrm{Pb})$.

\section{Kadar Timbal (Pb) dalam Rambut}

Pemeriksaan kadar timbal $(\mathrm{Pb})$ dalam rambut polisi lalu lintas dilakukan di Laboratorium Pertanian Unsoed. Pemeriksaan sampel rambut polisi lalu lintas dilakukan dengan menggunakan alat AAS (Atomic Absorbtion Specthrophotometer) dengan panjang gelombang lampu $\mathrm{Pb}$ adalah 217-218 $\mathrm{nm}$ dan kuat arus 3,5 mA.

Hasil pemeriksaan kadar timbal $(\mathrm{Pb})$ dengan menggunakan alat AAS (Atomic Absorbtion Specthrophotometer) menunjukkan rata-rata kadar timbal $(\mathrm{Pb})$ dalam rambut polisi lalu lintas adalah 6,02075 ppm, dengan kadar timbal $(\mathrm{Pb})$ dalam rambut tertinggi adalah 13,391 ppm dan terendah 0,999 ppm. Menurut Aditya Marianti dan Agung Tri Prasetya (2013) tingkat pencemaran timbal pada rambut dikategorikan pencemaran rendah jika $<10 \mathrm{ppm}$, sedang jika $10-25 \mathrm{ppm}$, dan tinggi apabila kadar timbal $(\mathrm{Pb})>25 \mathrm{ppm}$. Berdasarkan kriteria tersebut, kadar timbal $(\mathrm{Pb})$ dalam rambut polisi lalu lintas termasuk kategori pencemaran timbal $(\mathrm{Pb})$ tingkat sedang sebanyak 3 responden yaitu $\mathrm{AH}, \mathrm{GN}$ dan HR, sedangkan 9 lainnya tergolong dalam kriteria pencemaran rendah. Kadar timbal $\mathrm{Pb})$ dalam rambut setiap orang bisa berbedabeda tergantung pada konsentrasi timbal $(\mathrm{Pb})$ yang ada di lingkungannya dan lamanya seseorang terpapar timbal $(\mathrm{Pb})$.

Hasil penelitian menunjukkan kadar timbal $(\mathrm{Pb})$ dalam rambut responden termasuk dalam kategori rendah dan sedang, meskipun demikian timbal $(\mathrm{Pb})$ yang terdapat dalam rambut tersebut merupakan hasil akumulasi cemaran timbal yang dapat berasal dari berbagai sumber. Seperti yang disebutkan oleh H.J.Mukono (2002, h.144) timbal (Pb) di alam dapat berasal dari tambang timah hitam, pengecoran dan pemurnian, pencemaran dari proses tambang, Konsumsi serta pemakaian bahan yang mengandung timbal $(\mathrm{Pb})$, misalnya baterai dan bahan bakar / premium.

Responden dalam penelitian ini adalah polisi lalu lintas. Sebagian besar keseharian polisi lalu lintas berada di jalan raya untuk mengatur arus lalu lintas maupun menjalankan tugas-tugas yang lain seperti penilangan dan menangani kecelakaan lalu lintas. Sehingga besar kemungkinan responden terkontaminasi timbal $(\mathrm{Pb})$ yang bersumber dari emisi kendaraan bermotor akan tetapi disisi lain sumber kontaminasi timbal juga bisa akibat dari pola hidup yang tidak sehat seperti memiliki kebiasaan merokok atau perilaku saat bekerja.

Timbal $(\mathrm{Pb})$ diudara yang terhirup pada saat bernafas sebagian besar akan masuk ke dalam pembuluh darah paru-paru. Tingkat penyerapan tersebut sangat dipengaruhi oleh ukuran partikel dari senyawa timbal $(\mathrm{Pb})$ yang ada dan volume udara yang mampu dihirup pada saat bernafas. Makin kecil ukuran partikel debu, serta makin besarnya volume udara yang mampu terhirup maka akan semakin besar pula 
konsentrasi timbal $(\mathrm{Pb})$ yang diserap oleh tubuh. Timbal $(\mathrm{Pb})$ yang terhirup akan terserap dan berikatan dengan darah paru-paru untuk kemudian diedarkan keseluruh jaringan dan organ tubuh (Heryando Palar, 2004, h. 83).

Timbal $(\mathrm{Pb})$ yang diedarkan keseluruh tubuh tersebut nantinya akan terakumulasi pada jaringan lunak dan jaringan keras. Seperti yang di sebutkan oleh Darmono (1995, h. 97) bahwa timbal $(\mathrm{Pb})$ yang terhirup akan diabsorpsi oleh paru-paru dan akan masuk ke aliran darah. Pertama didistribusikan ke dalam jaringan lunak seperti tubulus ginjal dan sel hati, tetapi berinkorporasi dalam tulang, rambut, dan gigi untuk dideposit. Sehingga pemeriksaan kadar timbal $(\mathrm{Pb})$ dapat dilakukan dengan menggunakan rambut.

Timbal $(\mathrm{Pb})$ dalam tubuh dapat mengakibatkan keracunan. Keracunan timbal $(\mathrm{Pb})$ dapat terjadi perinhalasi atau dapat juga peroral uap atau debu yang mengandung timbal $(\mathrm{Pb})$. Unsur timbal $(\mathrm{Pb})$ disimpan dalam epitel, tubulus ginjal dan hati, kemudian didistribusikan lagi kedalam tulang, gigi, dan rambut sebagai garam fosfat (Ngatidjan, 2006, h. 162).

\section{Uji Statistik}

Data yang diperoleh kemudian dianalisis menggunakan uji korelasi Simple Regression untuk mengetahui hubungan masingmasing variabel independent dengan variabel dependent dan dianalisis menggunakan Uji Regressi Linier Ganda untuk mengetahui pengaruh masing-masing variabel independent setelah diuji secara bersama sama dengan variabel dependen.

\section{a. Hubungan Lama Merkok dengan Kadar Timbal (Pb) dalam Rambut Polisi Lalu Lintas}

Lama merokok responden memiliki rata-rata 2,9167 tahun, dari 12 responden hanya 4 yang memiliki kebiasaan merokok yaitu AA (10 Th), AH (10 Th), HR (10 Th), dan RK (5Th).

Kadar timbal $(\mathrm{Pb})$ dalam rambut tertinggi yaitu $\mathrm{AH}$ dengan kadar timbal $(\mathrm{Pb})$ sebesar 13,391 ppm dan yang terendah yaitu ES dengan kadar timbal $(\mathrm{Pb})$ sebesar 0,999 ppm. AH memiliki kebiasaan merokok selama 10 tahun ini, sedangkan ES tidak memiliki kebiasaan merokok, sehingga dapat dikatakan orang yang memiliki kebiasaan merokok memiliki peluang lebih besar untuk tercemar timbal $(\mathrm{Pb})$ dibandingkan orang yang tidak merokok.

Kondisi tersebut didukung oleh hasil uji statistik menggunakan uji korelasi Simple Regression yang menunjukkan terdapat hubungan moderat antara lama merokok dengan kadar timbal $(\mathrm{Pb})$ dalam rambut dengan nilai $R$ 0,504 $(R>0,5)$, dan $p$ $0,047(\mathrm{p}<0,05)$ sehingga $\mathrm{H}_{0}$ ditolak hal ini berarti ada hubungan yang signifikan antara lama merokok dengan kadar timbal $(\mathrm{Pb})$ dalam rambut.

Kadar timbal $(\mathrm{Pb})$ dalam rambut tidak hanya dipengaruhi oleh lama merokok akan tetapi banyaknya batang rokok yang dihisap perharinya juga dimungkinkan dapat mempengaruhi kadar timbal $(\mathrm{Pb})$ dalam rambut. Seperti yang disebutkan Sitepoe (2000) Rokok mengandung bahanbahan kimia salah satunya adalah timbal $(\mathrm{Pb})$. Timbal $(\mathrm{Pb})$ yang dihasilkan oleh sebatang rokok sebanyak $0,5 \mu \mathrm{g}$. Sebungkus rokok (isi 20 batang) yang habis dihisap dalam satu hari akan menghasilkan $10 \mu \mathrm{g}$.

Rokok adalah salah satu zat adiktif yang bila digunakan mengakibatkan bahaya bagi kesehatan individu dan masyarakat (Hans Tendra, 2003). Selain diketahui mengandung bahan-bahan kimia seperti timbal $(\mathrm{Pb})$, aktivitas merokok juga diketahui mengganggu efektifitas sebagian mekanisme pertahanan respirasi. Produk asap rokok dapat merangsang produksi mukus dan menurunkan pergerakan silia. Penurunan pergerakan silia dapat mempengaruhi terjadinya akumulasi mukus yang kental dan terperangkapnya partikel. Partikel yang terperangkap tersebut salah satunya timbal (Pb) (H.J. Mukono, 2010).

Penurunan pergerakan silia tersebut akan menurunkan fungsi dari silia untuk menyaring udara yang terhirup, sehingga udara yang mengandung timbal akan mudah masuk ke dalam paru-paru dan bercampur dengan darah untuk kemudian diedarkan oleh darah keseluruh tubuh (Betti Ronayan A, 2015).

Timbal $(\mathrm{Pb})$ yang diedarkan keseluruh tubuh tersebut nantinya akan terakumulasi pada jaringan lunak dan jaringan keras. Seperti yang di sebutkan oleh Heryando Palar (2004) juga menyebutkan timah hitam yang diabsorpsi diangkut oleh darah ke organ-organ tubuh sebanyak 95\% timbal $(\mathrm{Pb})$ dalam darah diikat oleh eritrosit. Sebagian timbal $(\mathrm{Pb})$ plasma dalam bentuk yang dapat berdifusi dan diperkirakan dalam keseimbangan dengan pool $\mathrm{Pb}$ tubuh lainnya, yang dibagi menjadi dua yaitu ke jaringan lunak (sumsum tulang, sistem saraf, ginjal, hati) dan ke jaringan keras (tulang, kuku, rambut, gigi). Sehingga pemeriksaan kadar timbal $(\mathrm{Pb})$ dapat dilakukan dengan menggunakan rambut.

Penelitian ini menunjukkan ada hubungan yang signifikan antara lama merokok dengan kadar timbal $(\mathrm{Pb})$ dalam 
rambut. Hasil penelitian ini sejalan dengan hasil penelitian Betti Ronayan A (2015) yang menunjukkan terdapat hubungan yang signifikan antara kebiasaan merokok (tahun) dengan kadar timbal $(\mathrm{Pb})$ dalam darah.

Hasil uji statistik menunjukkan nilai $\mathrm{R}^{2} \quad 0,254$ (pengkuadratan dari koefisien korelasi atau $0,504 \times 0,504=0,254)$ yang berarti nilai $0,254=25,4 \%(0,254 \times 100 \%)$, sehingga lama merokok dapat berpengaruh terhadap kadar timbal $(\mathrm{Pb})$ dalam rambut sebesar $25,4 \%$, sisanya $74,6 \%$ oleh variabel lainnya.

Semakin lama kebiasaan orang merokok maka juga akan mempengaruhi kadar timbal $(\mathrm{Pb})$ dalam rambut, sehingga untuk mengurangi pengaruh lama merokok terhadap kadar timbal $(\mathrm{Pb})$ dapat dilakukan dengan menghilangkan kebiasaan merokok tersebut atau berhenti merokok.

Hasil uji anova menunjukkan taraf signifikansinya $0,095>0,05(\alpha)$, berarti persamaan garis tidak dapat digunakan untuk memprediksi variabel Y. Sehingga persamaan garis tidak dapat dilanjutkan.

b. Hubungan Lama Bertugas dengan Kadar Timbal (Pb) dalam Rambut Polisi Lalu Lintas

Penyerapan timbal $(\mathrm{Pb})$ ke dalam tubuh dipengaruhi oleh beberapa faktor, salah satunya adalah lama bertugas. Pajanan timbal $(\mathrm{Pb})$ yang kontinyu selama 3 bulan sudah dapat menyebabkan dampak kesehatan. Pada polisi lalu lintas, faktor tingkat dan lamanya pajanan berkaitan erat dengan Lama bertugas. Pada umumnya, makin tinggi kadar dan lama pajanan makin tinggi pula kadar $\mathrm{Pb}$ dalam darah dan efek toksiknya akan lebih besar (Lu dalam Wahid Hasyim , 2008).

Hasil penelitan didapatkan ratarata lama bertugas polisi lalu lintas di Kabupaten Magelang adalah 7,33 tahun, dengan masa kerja paling banyak 15 tahun dan paling sedikit 3 tahun bertugas sebagai polisi lalu lintas. Responden yang telah bertugas selama 15 tahun yaitu ES dengan kadar timbal $(\mathrm{Pb})$ sebesar 0,999 ppm sedangkan responden dengan lama bertugas 3 tahun yaitu HR memiliki kadar timbal $(\mathrm{Pb})$ dalam rambutnya sebesar 11,405 ppm.

Hasil uji statistik menggunakan uji korelasi Simple Regression menunjukkan terdapat hubungan lemah antara lama bertugas dengan kadar timbal $(\mathrm{Pb})$ dalam rambut dengan nilai $\mathrm{R} 0,434(\mathrm{R}<0,5)$, dan $\mathrm{p}$ $0,080(\mathrm{p}>0,05)$ sehingga $\mathrm{H}_{0}$ diterima hal ini berarti tidak ada hubungan yang signifikan antara lama bertugas dengan kadar timbal $\mathrm{Pb})$ dalam rambut atau lama bertugas tidak berpengaruh terhadap kadar timbal $(\mathrm{Pb})$ dalam rambut.

Lama bertugas dikatakan bisa mempengaruhi kadar timbal $(\mathrm{Pb})$ dalam tubuh seseorang karena semakin lama masa kerja maka semakin lama pula paparannya. Semakin lama paparan maka timbunan timbal didalam tubuh juga akan semakin banyak (Cecilia Oktaria P, 2009).

Lama bertugas dalam penelitian ini diasumsikan dalam tahun dan hasil uji statistik menunjukkan lama bertugas tidak berpengaruh terhadap kadar timbal $(\mathrm{Pb})$ dalam rambut. Kondisi tersebut mungkin saja terjadi karena kadar timbal $(\mathrm{Pb})$ tidak hanya dipengaruhi oleh lama bertugas melainkan karena faktor yang lain. Faktor lain tersebut diantaranya yaitu lama paparan perharinya, kebiasaan merokok, kondisi lingkungan bekerja, kedisiplinan dalam menggunakan APD (masker), dll.

Kondisi lingkungan kerja dan Jam kerja dilapangan perharinya juga dimungkinkan dapat mempengaruhi kadar timbal $(\mathrm{Pb})$ dalam rambut. Jam kerja dilapangan perharinya berbeda-beda antara orang satu dengan yang lainnya. ES telah bekerja selama 15 tahun sebagai polisi lalu lintas akan tetapi pajanan yang diterima perharinya hanya selama 4 jam saja, ES juga tidak memiliki kebiasaan merokok. Selain itu tempat kerja ES merupakan jalanan dengan arus lalu lintas yang paling rendah dan sepanjang jalan tempat ES bertugas merupakan jalan yang terdapat banyak pepohonan.

Tumbuhan atau pohon dapat menyerap zat-zat pencemar seperti timbal $(\mathrm{Pb})$, baik yang terdapat ditanah, air, maupun di udara. Tumbuhan dapat mereduksi kandungan logam berat $\mathrm{Pb}$ melalui penyerapan dari tanah atau melalui stomata daun (wahid Hasyim, 2008), sehingga dimungkinkan timbal $(\mathrm{Pb})$ yang masuk kedalam tubuh sangat sedikit. Sedangkan HR yang baru bertugas sebagai polisi lalu lintas selama 3 tahun memiliki kadar timbal $(\mathrm{Pb})$ yang tinggi. Kondisi tersebut terjadi dimungkinkan karena lama bertugas HR di lapangan perharinya 12 jam dan memiliki kebiasaan merokok selama 10 tahun ini. Selain itu tempat bertugas HR tiap harinya merupakan jalanan dengan arus lalu lintas yang tinggi serta tidak terdapat pepohonan yang rindang di sepanjang jalan HR bertugas.

Lama bertugas tidak berpengaruh terhadap kadar timbal $(\mathrm{Pb})$ dalam rambut. 
Selain karena faktor diatas, juga diduga karena faktor alam diantaranya kecepatan angin dan curah hujan. Kecepatan angin akan mempengaruhi kadar timbal $(\mathrm{Pb})$ diudara dimana emisi bahan bakar kendaraan yang tinggi akan terbawa oleh angin dan terjadi persebaran secara cepat. Begitu juga dengan curah hujan akan berpengaruh terhadap polusi di udara. Kadar timbal $(\mathrm{Pb})$ di udara akan terbawa oleh air hujan dan secara gravitasi akan turun bersaman dengan air hujan. Curah hujan pada bulan maret saat penelitian dilakukan yaitu $8.016 \mathrm{~mm}$.

Penelitian ini menunjukkan tidak ada hubungan antara lama bertugas dengan kadar timbal $(\mathrm{Pb})$ dalam rambut . Hasil penelitian Wahid Hasyim (2008) juga menunjukkan tidak terdapat hubungan yang signifikan antara masa kerja dengan kadar timbal $(\mathrm{Pb})$ dalam darah polisi lalu lintas di Kepolisian Resort Kebumen.

Hasil uji statistik menunjukkan nilai $\mathrm{R}^{2} \quad 0,188$ (pengkuadratan dari koefisien korelasi atau 0,434 x 0,434= 0,188 ) yang berarti nilai $0,188=18,8 \%$ $(0,188 \times 100 \%)$, sehingga lama bertugas dapat berpengaruh terhadap kadar timbal $(\mathrm{Pb})$ dalam rambut sebesar $18,8 \%$, sisanya $81,2 \%$ oleh variabel lainnya.

Upaya yang bisa dilakukan untuk mengurangi paparan timbal $(\mathrm{Pb})$ dapat dilakukan dengan membagi shift bertugas dijalan raya pada masing-masing Pos jaga, penggunaan masker juga bisa dilakukan serta sebaiknya dilakukan penanaman pohon atau pembuatan jalur hijau di sepanjang jalan raya.

Taraf signifikansi pada uji anova menunjukkan $0,159>0,05$, sehingga persamaan garis tidak dapat digunakan untuk memprediksi variabel Y. Dengan demikian persamaan garis tidak dapat di lanjutkan.

c. Hubungan Arus Lalu Lintas Kendaraan dengan Kadar Timbal (Pb) dalam Rambut Polisi Lalu Lintas

Arus lalu lintas kendaraan di Kabupaten Magelang memiliki rata-rata 4.620,33 kend/jam, dengan arus lalu lintas kendaraan tertinggi yaitu di Pos Armada sebesar $8.944 \mathrm{kend} / \mathrm{jam}$ dan terendah sebesar 2.268,33 kend/jam di Sawitan. Arus lalu lintas kendaraan di wilayah kerja Pos Armada didominasi oleh sepeda motor sebesar $5.176 \mathrm{kend} / \mathrm{jam}$, begitu pula di sawitan juga didominasi oleh sepeda sebesar 1.826,66 kend/jam.

Pos Armada memiliki arus lalu lintas paling tinggi dikarenakan berada di depan simpangan antara arah menuju ke Provinsi Yogyakarta, Kabupaten Purworejo, Kota Magelang serta arah menuju Kabupaten Semarang. Selain simpangan tersebut Pos Armada juga berdekatan dengan Artos Mall sehingga aktivitas kendaraan di sekitar wilayah kerja Pos Armada selalu ramai, sedangkan disawitan arus lalu lintasnya rendah selain itu di lingkungan pos sawitan tertanam banyak pepohonan.

Responden yang bertugas di Pos Armada berjumlah 3 orang yaitu AA dengan kadar timbal $(\mathrm{Pb})$ sebesar 4,618 ppm, AH dengan kadar timbal $(\mathrm{Pb})$ dalam rambut sebesar 13,391 ppm, dan HR dengan kadar timbal $(\mathrm{Pb})$ dalam rambut sebesar 11,405 ppm. Kadar timbal $(\mathrm{Pb})$ dalam rambut $\mathrm{AH}$ dan $\mathrm{HR}$ tergolong dalam kriteria pencemaran sedang. Responden yang bertugas di Sawitan sebanyak 6 orang, semuanya memiliki kadar timbal $(\mathrm{Pb})$ dalam rambut dengan tingkat pencemaran rendah.

Hasil uji statistik menggunakan uji korelasi Simple Regression menunjukkan terdapat hubungan kuat antara arus lalu lintas kendaraan dengan kadar timbal $(\mathrm{Pb})$ dalam rambut dengan nilai $\mathrm{R} \quad 0,661$ $(\mathrm{R}>0,5)$, dan $\mathrm{p} 0,010(\mathrm{p}<0,05)$ sehingga $\mathrm{H}_{0}$ ditolak hal ini berarti ada hubungan yang signifikan antara arus lalu lintas kendaraan dengan kadar timbal $(\mathrm{Pb})$ dalam rambut.

Polusi timbal $(\mathrm{Pb})$ terbesar berasal dari pembakaran, dikarenakan jumlah senyawa timbal $(\mathrm{Pb})$ yang jauh lebih besar didalam bahan bakar dibandingkan senyawa-senyawa lain yang tidak terbakar. Musnahnya timbal $(\mathrm{Pb})$ dalam peristiwa pembakaran pada mesin menyebabkan jumlah timbal $(\mathrm{Pb})$ yang dibuang ke udara bersama asap buangan kendaraan menjadi sangat tinggi dan dihasilkan berbagai komponen timbal $(\mathrm{Pb})$ terutama $\mathrm{PbBrCl}$ (Heryando Palar, 2004, h. 79).

Lingkungan kerja mempunyai pengaruh dalam absorbsi senyawa timbal $(\mathrm{Pb})$ ke dalam tubuh (wahid Hasyim, 2008). Lingkungan kerja dengan pajanan timbal $\mathrm{Pb})$ yang tinggi akan menyebabkan seorang polisi lalu lintas mempunyai risiko terpajan $\mathrm{Pb}$ yang tinggi pula.

Arus lalu lintas yang tinggi akan menghasilkan emisi kendaraan yang banyak dan konsentrasi polusi diudara juga akan tinggi, seperti yang disebutkan De Roes FJ (Wahyu Kurniawan, 2008) bahwa Kandungan timbal $(\mathrm{Pb})$ di udara sangat berhubungan dengan padat tidaknya arus lalu lintas kendaraan bermotor. Kondisi 
demikian mengakibatkan polisi lalu lintas yang bertugas di lingkungan dengan arus lalu lintas yang tinggi memiliki resiko terpajan timbal $(\mathrm{Pb})$ lebih besar dibandingkan polisi yang bertugas dengan kondisi arus lalu lintas yang rendah.

Hasil uji statistik menunjukkan nilai $\mathrm{R}^{2} \quad 0,437 \quad$ (pengkuadratan dari koefisien korelasi atau 0,661 x 0,661 = 0,437 ) yang berarti nilai $0,437=43,7 \%$ $(0,437 \times 100 \%)$, sehingga arus lalu lintas kendaraan dapat berpengaruh terhadap kadar timbal $(\mathrm{Pb})$ dalam rambut sebesar $43,7 \%$, sisanya $56,3 \%$ oleh variabel lain.

Pengurangan konsentrasi timbal $(\mathrm{Pb})$ di udara bisa dilakukan dengan pembuatan jalur hijau misalkan menggunakan pohon angsana. Penelitian Rinawati (2010) menyebutkan tanaman angsana (Pterocarpus Indcus) dapat dijadikan sebagai salah satu alternatif tanaman perindang jalan (penghijauan) sebagai upaya menanggulangi penurunan kualitas lingkungan karena mempunyai daya serap terhadap timbal $(\mathrm{Pb})$ di udara.

Paparan timbal $(\mathrm{Pb})$ dari emisi kendaraan juga dapat dikurangi dengan diadakannya rotasi kerja, baik rotasi ke Pos lain maupun ke bidang yang lainnya, selain itu penggunaan masker saat bertugas di jalan raya juga diperlukan. Penggunaan masker dapat meminimalisir terhirupnya partikel melalui inhalasi dikarenakan ukuran partikel timbal $(\mathrm{Pb})$ yang kecil, seperti yang disebutkan oleh Saeni (Cecilia Oktaria $\mathrm{P}, 2009)$ partikel timbal $(\mathrm{Pb})$ yang dikeluarkan oleh gas buang kendaraan bermotor berukuran antara $0,080-1,00 \mu$. Sehingga dengan pemakaian masker dapat mengurangi partikel timbal $(\mathrm{Pb})$ yang terhirup.

Uji anova menunjukkan taraf signifikansi 0,019, sehingga persamaan garis regressi dapat digunakan untuk memprediksi variabel Y. Dengan demikian persamaan garis dapat dilanjutkan. Hasilnya sebagai berikut:

$$
\mathrm{Y}=\beta_{0}+\beta_{1} . \mathrm{X}
$$

Kadar timbal $(\mathrm{Pb})$ dalam rambut $=1,854+$ 0,001. Arus lalu lintas

\section{d. Hubungan Lama Merokok, Lama Bertugas, dan Arus Lalu Lintas Kendaraan dengan Kadar Timbal (Pb) dalam Rambut Polisi Lalu Lintas \\ Pengaruh semua variabel} independen terhadap kadar timbal $(\mathrm{Pb})$ dalam rambut setelah dianalisis statistik secara bersamaan menggunakan Uji Regressi Linier Ganda, hasil analisis menunjukkan dari tiga variabel independen yang diuji secara bersama-sama, hanya menghasilkan satu variabel yang signifikan yaitu arus lalu lintas kendaraan dengan nilai p 0,019 $(\mathrm{p}<0,05)$ dan nilai $\mathrm{R} \quad 0,661$. Sehingga variabel yang paling berhubungan dengan kadar timbal $(\mathrm{Pb})$ dalam rambut adalah arus lalu lintas.

Nilai koefisien determinasinya 0,381 , yang berarti nilai $0,381=38,1 \%$ $(0,381$ x $100 \%)$ sehingga setelah diuji bersama-sama dengan variabel lainnya, arus lalu lintas dapat berpengaruh terhadap kadar timbal $(\mathrm{Pb})$ dalam rambut sebesar $38,1 \%$, sisanya $61,9 \%$ oleh variabel lain.

\section{IV.KESIMPULAN}

Analisis bivariat dengan uji korelasi Simple Regression didapatkan dua variabel yang berhubungan dengan kadar timbal $(\mathrm{Pb})$ dalam rambut yaitu lama merokok ( $\mathrm{R} 0,504 ; \mathrm{p} 0,047)$ dan arus lalu lintas kendaraan ( $\mathrm{R}$ 0,661;p 0,019) sedangkan dari uji multivariat menggunakan Uji Regressi Linier Ganda didapatkan hasil tidak terdapat hubungan antara lama merokok, lama bertugas dan arus lalu lintas dengan kadar timbal $(\mathrm{Pb})$ dalam rambut Polisi Lalu Lintas. Dari uji secara bersama-sama didapatkan satu variabel yang signifikan yaitu arus lalu lintas kendaraan dengan nilai p 0,019 ( $<<0,05)$ dan nilai $R$ 0,66. Saran bagi peneliti lain perlu dilakukan penelitian lebih lanjut mengenai penelitian yang sejenis pada tempat lain atau dengan variabel lain yang disertai dengan dampak terhadap kesehatan, perlu dilakukan penelitian mengenai hubungan lama merokok yang diasumsikan berapa lama responden merokok dalam tahun dan banyakanya batang rokok yang dihisap perhari, serta perlu dilakukan penelitian mengenai hubungan lama bertugas yang diasumsikan berapa jam responden kontak dengan timbal $(\mathrm{Pb})$ atau bertugas dijalan raya perharinya.

\section{DAFTAR PUSTAKA}

Aditya Marianti dan Agung Tri Prasetya, 2013, Rambut Sebagai Bioindikator Pencemaran Timbal Pada Penduduk Di Kecamatan Semarang Utara, Jurnal penelitian, Semarang: Universitas Negeri Semarang, at http://download.portalgaruda.org, diakses tanggal 28 Januari 2016.

Amrinal Ramzi, 2014, “Edukasi Bahan Bakar Bagi Mekanik Motor Yamaha”, Artikel, Jakarta, at http://www.pertamina.com, diakses tanggal 26 Januari 2016.

Aris Santjaka, 2011, Statistik Untuk Penelitian Kesehatan (Deskriptif, Inferensial, Parametrik Dan Non Parametrik), Yogyakarta: Nuha Medika 
2015, Aplikasi SPSS Untuk Analisis Data Penelitian Kesehatan, Yogyakarta: Nuha Medika

Betti Ronayan A, 2015, Hubungan Karakteristik Individu Terhadap Kadar Timbal Dalam Darah Dan Dampaknya Pada Kadar Hemoglobin Pekerja Percetakan Di Kawasan Megamall Ciputat, Skripsi, Jakarta: Universitas Islam Negeri Syarif Hidayatullah,

at http://repository.uinjkt.ac.id, diakses tanggal 18 Juni 2016

Cecilia Oktaria P, 2009, Pengaruh Masa Kerja Terhadap Kejadian Gingival Lead Line Pada Polisi Lalu Lintas Di Kota Semarang, Karya Tulis Ilmiah, Semarang: Fakultas Kedokteran Universitas Diponegoro Semarang

Darmono, 1995, Logam Dalam Sistem Biologi Makhluk Hidup, Jakarta: Penerbit Universitas Indonesia

2006, Lingkungan Hidup Dan Pencemaran Hubungannya Dengan Toksikologi Senyawa Logam, Jakarta: Penerbit Universitas Indonesia

Diana Aulia, 2013, Faktor-Faktor Yang Berhubungan Dengan StresKerjaPada Polisi Lalu Lintas Di Polres Metro Jakarta Pusat, Jakarta: Universitas Islam Negeri Syarif Hidayatullah Jakarta.

Fardiaz. 2001. Polusi Air dan Udara. Jogyakarta: Kanisius.

Hadi Winarso, 2010, Faktor-Faktor Yang Mempengaruhi Kadar Pb Dalam Darah Petugas SPBU Di Kota Purwokerto, Skripsi, Purwokerto: Poltekkes Kemenkes Semarang

Hans Tendra, 2003, Merokok dam Kesehatan, Jakarta, at http://www.bukukita.com , diakses tanggal 8 Februari 2016

Heryando Palar, 2004, Pencemaran Dan Toksikologi Logam Berat, cetakan kedua, Jakarta: PT Rineka Cipta

Hoeve, Van, 1990, Ensiklopedia Indonesia, Jakarta

Juli Soemirat, 2009, Kesehatan Lingkungan, Yogyakarta: Gadjah Mada University Press (Anggota IKAPI)

Kusdwiratri Setiono, Johan S Mansyur, Anna Alisyahbana, Manusia, Kesehatan Dan
Lingkungan, Bandung: Yayasan Adikarya (IKAPI)

Librawati, T.P., 2005, Analisis Cemaran Pb pada Bawang Daun (Allium fistulosum L)di daerah Dieng Wonosobo , Skripsi, Purwokerto: Fakultas Biologi Universitas Jenderal Soedirman Purwokerto.

Morlok, E.K., Introduction To Transportation Engineering And Planning, New York: McClaw-Hill Book Company, at http://facweb.knowlton.ohio-state, diakses tanggal 24 Januari 2016

Mukono, H.J., 2002, Epidemiologi Lingkungan, Surabaya: Airlangga University Press

2010, Toksikologi Lingkungan, cetakan kedua, Surabaya: Airlangga University Press

Ngatidjan, 2006, Toksikologi Racun, Keracunan, Dan Terapi Keracunan, Yogyakarta: Bagian Farmakologi dan Toksikologi Fakultas Kedokteran Universitas Gadjah Mada

Nira Yuniati, 2008, Cemaran Timbal (Pb) Pada Rambut Dan Kuku Pegawai Pelayan Fotokopi Di Wilayah Bogor, Skripsi, Bogor: Departemen Biologi Fakultas Matematika Dan Ilmu Pengetahuan Alam Institut Pertanian Bogor, at http://repository.ipb.ac.id, diakses tanggal 16 November 2015

Normala Fadlilah, 2009, Penelitian Kadar Timbal Dalam Rambut Siswa Sekolah Dasar Di Surakarta (Penelitian di SD Islam Nadhatul Muslimah dan SD 6 AL Islam Al Fajar Surakarta), Tesis, Semarang: Universitas Diponegoro, at http://eprints.undip.ac.id, diakses tanggal 16 November 2015

Rinawati, 2010, Studi Kadar Timah Hitam (Pb) Pada Tanaman Angsana (Pterocarpus indicus) Di Jalan Derilya Purwokerto, Karya Tulis Ilmiah, Purwokerto: Poltekkes Kemenkes Semarang

Sadjijono, 2008, Polri Dalam Perkembangan Hukum Di Aindonesia (Berbagai Pemikiran Tentang Paradigma Polri Menuju Polri Ysng Bermorsl, Profesionl, Modern Dan Mandiri), Yogyakarta: Laksbang Presindo, at http://old.lib.ugm.ac.id , diakses tanggal 26 Januari 2016 
Saeni, M.S., 1998, Kimia lingkungan : Majalah Kedokteran Indonesia

Shilu Tong, Yasmin E. Von Schirnding, Taippawan Propamontol, 2000, Bulletin of The World Health Organization Environmental Lead Exposure, a Public Health Problem of Global Dimension, at http://www.who.int/bulletin/.pdf, diakses tanggal 20 November 2015

Siswanto A, 1991, Toksikologi Industri, Surabaya: Balai Hiperkes Dan Keselamatan Depnaker Jatim

Sitepoe, M., 2000, Kekhususan Rokok Indonesia, Jakarta: PT Gramedia Widiasarana Indonesia, at

Srikandi Fardiaz, 2011, Polusi Air Dan Udara, cetakan keempat belas, Yogyakarta: Penerbit Kanisius (Anggota IKAPI)

Sutanto Priyo Hastono, 2001, Analisis Data, Depok: Fakultas Kesehatan Masyarakat Universitas Indonesia

Sylvia Indriany, 2011, Rekayasa Transportasi, at http://kk.mercubuana.ac.id, diakses tanggal 3 Januari 2016

Tresna Sastrawijaya, A., 2009, Pencemaran Lingkungan, cetakan ketiga, Jakarta: PT Rineka Cipta

Wahid Hasyim, 2008, Hubungan Antara Masa Kerja Dengan Kadar Timbal (Pb) Dalam Darah Polisi Lalu Lintas Di Kepolisian Resort (Polres) Kebumen, Skripsi, Purwokerto: Universitas Jenderal Soedirman Fakultas Kedokteran Dan IlmuIlmu Kesehatan Jurusan Kesehatan Masyarakat
Wahyu Hardinsyah Putra, Bintal Amin, Sofia Anita, 2014, Kadar Timbal (Pb) Pada Rambut Dan Kuku Polisi Lalu Lintas Di Kota Pekanbaru Dan Kota Bengkalis. Dalam Riset: Dinamika Lingkungan Indonesia, at http://download.portalgaruda.org/article, diakses tanggal 23 November 2015

Wahyu Kurniawan, 2008, Hubungan Kadar Pb Dalam Darah Dengan Profil Darah Pada Mekanik Kendaraan Bermotor Di Kota Pontianak, Tesis, Semarang: Program Pasca Sarjana Universitas Diponegoro Semarang, http://core.ac.uk , diakses tanggal 12 Mei 2015

Wahyu Widowati, Astiana Sastiono, Raymond Jusuf R, 2008, Efek Toksik Logam, Yogyakarta: C.V ANDI OFFSET

Wirsal Hasan, Abdul Rahim Matondang, Alvi Syahrin, Chatarina, 2013, Pengaruh Jenis Kelamin dan Kebiasaan Merokok terhadap Kadar Timbal Darah. Dalam Riset: Jurnal Kesehatan Masyarakat Nasional Vol. 8, No. 4, November 2013, at http://download.portalgaruda.org/article, diakses tanggal 18 Juni 2016

World Health Organitation (WHO), 2005, Bahaya Bahan Kimia Pada Kesehatan Manusia Dan Lingkungan, Jakarta: Penerbit Buku Kedokteran EGC

Yustin M Manglapy, MG Catur Yuantari, 2009, Faktor-Faktor Yang Berhubungan Dengan Kadar Timah Hitam (Pb) Dalam Darah Operator SPBU Coco Di Jl.Ahmad Yani Semarang, Dalam Riset: Jurnal Visikes Vol. 8, No. 2, September 2009, at http://dinus.ac.id diakses tanggal 19 Juni 2016 